\title{
Strategic Management Key to Success for Kosovo Companies - Expansion in International European Market
}

\author{
Msc. Arjanit Avdiu \\ University of Prizren, Prizren, Kosovo \\ Rrezarta Gashi \\ PhD professor- AAB University, \\ Prishtinë, Kosovo
}

\begin{abstract}
A recent signed Stabilisation and Association Agreement (SAA), an platform that promotes harmonious economic relations and gradually development of a free trading areas between EU and Kosovo', encouraged many companies from this country to start thinking big for international business expansion in Europe. Access in Europe via free trade, is a mine of gold opportunity since it allows reaching a large number of customers in a vast and broad market. Getting and even more competing with European and other international companies for a slight market share, obviously it is a hard "piece of cake". Path to be paved attaining business objectives could be more easily headed applying an appropriate management strategy. Strategic thinking, strategic planning, strategic marketing, and international managerial strategy are pillars that could support and craft any company have a proper approach and successive performance into European market environment.
\end{abstract}

Keywords: Strategic management, SAA, Free Trade, European market, Market expansion.

\section{Introduction}

From early stages of open international markets, collision between businesses that seek entering into new markets and those that attempt to protect current marketplace and market-shares are ongoing and endless. The impact of global competition is being felt in every industry. Firms and countries long used to dominate in their respective international markets must reckon with aggressive and innovative competitors from all concerns of the globe (Inkpen \& Ramanswamy, 2006). Economical open policies in region of Western Balkans in particular the European Union policy for Stabilization and Association Agreement (SAA) ${ }^{2}$, is seen as an opportunity enabling and at the same time encouraging many companies from Kosovo to take a big leap by joining European free-trade market. "This agreement is a milestone for the EU-Kosovo relationship. It will help Kosovo make much needed reforms and will create trade and investment opportunities. It will put Kosovo on the path of a sustainable economic growth" (Hahn, 2015). Given that majority of businesses for long time were accommodated to circumstances and conditions of almost closed market within boundaries of native country, to be mentioned some exceptions of CEFTA agreement bonded amongst South Eastern European countries, nowadays it's obvious that boundless and large European free market requires almost totally different operation commitments. Hence, path to accessing big free European market encompasses besides strict standardized rules and regulations, it also requires an "unwritten law" which companies itself are aware in order to succeed - change of current operation strategies. Clue conquering obstacles, prevailing upon and progressing continuously towards settling into new big and boundless European market for Kosovo businesses as

\footnotetext{
${ }^{1}$ Council of the European Union: STABILISATION AND ASSOCIATION AGREEMENT BETWEEN THE EUROPEAN UNION AND THE EUROPEAN ATOMIC ENERGY COMMUNITY, OF THE ONE PART, AND KOSOVO*, OF THE OTHER PART -Article 1, page 10.

2 Council of the European Union: STABILISATION AND ASSOCIATION AGREEMENT BETWEEN THE EUROPEAN UNION AND THE EUROPEAN ATOMIC ENERGY COMMUNITY, OF THE ONE PART, AND KOSOVO*, OF THE OTHER PART
} 
novice market players, is modification of currents strategic management way of operations into much more contemporary and advances strategic managerial approaches. EU market could be seen as a gate of many opportunities for business expansion, indeed, but entrance and expansion intending a sustainable operation abroad are achieved with selected an appropriate strategy even though it's so obvious that headway has numbers of significant hindrances to overcome. Importance of strategic management in businesses is proven to be an important contribution factor and a necessary tool making a stream of movements from vagueness and ambiguity situations toward bright and sustainable successive operational business. "The goal of the strategy is to beat competition, but before you test yourself against the competition; strategy takes shape in the determination to create value for the customer" (Ohmae at Abraham, 5, 2012).

Research paper through expression of original description derived from qualitative methods supported by abundant literature and quantitative data making it a highly valuable paper, has a purpose to present the best ideas making companies understand and utilize strategies available for new market expansion. Surely, paper will also be a useful guide and can be used as a prime for many businesses that aspire to enter into the EU and other major markets worldwide. While by offering many examples and providing practical examples, doubtlessly this research paper can be beneficiary for Kosovo businesses to prosper in EU and other international cross cultural markets.

\section{Strategic Thinking}

Access to EU market for many businesses of Kosovo may seem a new venture and an ongoing challenge, so doom of participating in such vast trading environment must probably require an up-to-date strategy application as a compulsory modification from local traditional or better saying in many occasions conservative business strategies to ones suitable at new market environment. Any initiation for strategy modification, improvement or even change it is firmly rooted in strategic thinking as basement for solid business operation. According to DiVanna who believes that strategy development is shifting from a function traditionally restricted to an elite group within a company to a process in which strategic thinking must now aggregate across an organization's many level into cohesive set of strategic initiatives that are driven by sensing changes in the business environment. To make this transition successful, corporations must integrate the act of strategy development into the fabric of their business processes making them able to sense changes in the business climate and initiate tactical adjustments based on preconceived scenarios (DiVanna\& Austin, 2004).

Strategic thinking is the mind-set, frame of reference or paradigm that takes an initial focus on mega results (that is, positive societal impact) and defines the future we want to help create for the future. Using it allows for the continues adjustment and adaptation to the changing realities, thus creates the future instead of simply reacting to it (Kaufman, Browne, Watkins \& Leigh, 16, 2003). Strategy as its heart is about positioning for the future competitive advantage. That is its

essence. Any strategic thinking must reflect this essence. It is the purpose that drives strategy. Nonetheless, purpose of the strategic thinking as a part of overall strategy is gaining and sustaining a competitive advantage. Devising a sound a strategy is impossible without strategic thinking. Coming up with different, plausible strategic alternatives is both creative and conceptual, but must also be grounded in a broad knowledge of the relevant industries, competitors, markets, technologies and other trends. Strategic thinking should not be done just when a firm engages in strategic planning, but rather all time. It requires a deep understanding of how markets and competitors are changing and of where opportunities may lie in order to determine a better strategic alternative exist and what it is (Abraham, 2012).

While Sloan expresses that, once we have an understanding of what strategic thinking is, we can proceed with endless options for development. The purpose of strategic thinking is to suspend problem solving and in a rigorous process of examination, exploration and challenge of the underlying premise of the strategy; and to generate new options as means to create a winning innovative and sustainable strategy (Sloan, 2014).

Another wise and useful thought depicting strategic thinking based on her personal experience, Ann Herrmann-Nehdi a CEO of Herrmann International, states that: strategic thinking is a mindset that allows to:

1)Anticipate future events and issues,

2) Create alternative scenarios, 
3)Understand your options,

4)Decide on your objectives,

5)Determine the direction to achieve those objectives on a winning basis.

Moreover, she also added that once you have accomplished the latter, a plan may be developed. Without a strategic thinking approach as the foundation, so-called strategic plans end up frequently becoming operational practical plans in disguise (Herrmann-Nehdi).

\section{Strategic Planning}

Obviously, a great deal of strategic thinking must go into developing a strategic plan and, once developed, a great deal of strategic management is required to bring its aims to fruition. But, as several authors have pointed out, the objective is indeed to think and manage strategically, not to blindly engage in strategic planning for the sake of strategic planning (Nickols, 2016). This could be an essential advice for Kosovo companies avoiding to create a mere blueprint but making a

firm strategic plan with clear goals for future realistic achievements, instead. About the significance of strategic planning Simerson (2011) counsels that it requires consideration of external and internal factors: evaluate what and where business or company currently stands and where it hopes becoming; considering alternate futures, various intents and goals, recognize resource limitations, uncertainties and therefore formulate contingencies; prioritize options for whatever future actions needed to be taken likely to yield the most optimal results and outcomes consistent with the organization's mission and vision.

A consistent and well prepared strategic planning for businesses must have five major components that provide neat and precise answers such are:

1. Analysis: Where we are now? What are our internal strengths and weaknesses and external opportunities and threats?

2. Formulation: What are our mission and vision? What is our sweet spot? What are our strategic intents and goals? Means of strategy to accomplish the goals?

3. Action Planning: How could strategic goals be translated into specific and concrete tactics? What kinds of obstacles are most likely to be faced and how to resolve unexpected occurrences?

4.Execution: What steps could be taken to ensure subsequent execution throughout the entire organization?

5. Continues Improvement: What can company do to constantly and continuously improve strategic planning processes thru ongoing operations? (Simerson, 10, 2011).

Substantially, strategic planning is backbone support to strategic management. It is not, of course, the entirety of strategic management but is as a major process in the conduct of strategic management. Strategic planning is part of the total planning process that includes management and operational planning precisely it consist of developing concepts ideas, and plans for achieving business successfully and for meeting and beating competition (Steiner, 1979).

\section{Strategic Marketing}

The primary role of strategic marketing is to identify and create value for the business through strongly differentiated positioning. The businesses achieve this by influencing the strategy and culture of the organization in order to ensure that both have a strong consumer focus. Moreover, strategic marketing is about choices that consumer-focused organizations make on where and how to compete and with what assets. It is also about developing a specific competitive position

using tools from the marketing armory including brands, innovation, customer relationships and services, alliances, channels and communications, and a very well defined price strategy, as well. The concept of strategic management draws heavily on the theory and practice of strategic management not just of marketing. This is an important distinction since strategic marketing is a much a part of directing how the organization competes as it is a part of marketing 
itself. In other words, strategic marketing is the "glue" that connects many aspects of the businesses towards major company goal achievements (Ranchhod \& Marandi, 2005).

According to Sahaf, strategic marketing sought to address two main issues like which market to enter and how to compete in those markets which fall within the scope of a strategic dimension of an organization or business. Bearing in mind that strategic marketing is very vast and immense field to talk about, due to the connection of issues we based our focus on marketing orientation as a strategic perspectives that suits the best for businesses of Kosovo aiming to enter into EU and wide markets, though. Basically, our statement is further proven that perspective of market orientation asserts that marketing must be concerned with making available what consumers want rather than with trying to persuade people to buy what the firms finds it convenient, congenial or just profitable to make. Thus, market oriented businesses are characterized by a consistent focus by employees in all departments and all levels on consumers' needs and competitive circumstances in market environment (Sahaf, 2013). Prerequisites for a successful and strong market orientation suggestion are portrayed in a figure given beneath by Narvar and Slate (Narvar \& Slate at Sahaf, 2013).

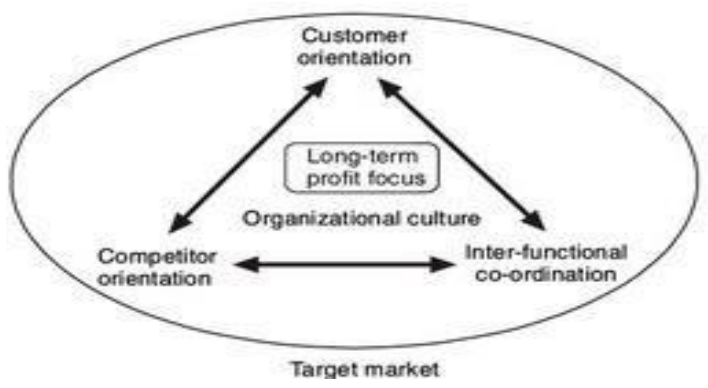

Figure 1. A model of Market Orientation

Sources: "Strategic Marketing: Making Decisions for Strategic Advantage"

\section{International Strategic Management}

For decades businesses have realized that emerging markets have become increasingly important for international companies not only as a source of inexpensive labor, but also as a source market

growth. At the present time, moreover, we witness that an increasing number of companies founded in emerging countries are accelerating their efforts to integrate into global economy (Hoskisson at Tallman, 2007). International strategic management is seen in the environment driven strategies of successful businesses competing in a diverse market. Due to ongoing dramatically changing global market environment, businesses should take into account some characteristics that inescapable could be encountered on way. As for instance to be mentioned few: A) Strategic management is a necessary process of gaining competitive advantage, requiring the active participation of all functions areas. B) The environmental, ethical, product quality, and integrity aspects of business practice are critical concern requiring active support, commitment and involvement of top management. C) Development of international strategies in some occasions could be complex process because of the existence of trade blocks such are EU, ASEAN, and NAFTA. D) Strategies increasingly involve inter-organizational teams and strategic alliances on global scale, redirecting the company focus on customer and global competition (Alkhafaji, 2003).

Developing the right business strategy, according to Aaker \& McLoughlin (2010), is a basic goal, but it is not the end of the story. With a proper business strategy in hand, the task is to continuously challenge the strategy in order to make sure that it remains relevant to the changing marketplace and responsive to emerging opportunities. Meanwhile, it has to ensure that organization develops and retain necessary skills and competencies to make strategy succeed. Accessing new markets, especially those with strict requirements and policies, the most secured path with less strategic 
concerns, international strategic alliance is perceived as a vivid outlook for international expansion and sustainable presence for businesses wide. Having known the experience and capacity of Kosovo companies in the international markets, the best and most appropriate strategy chosen would surely be strategy alliance with companies of the same field of operation from Europe. Strategic alliances are seen as proper mechanism hedging risks, thus, according to Contractor and Lorange (at Buckley, 1998), they indentified ways of reducing risks, thru: enabling product diversification, enabling faster market entry and quicker establishment of presence in the market, lowering cost of total investments of particular project or the assets of risk by combining expertise and slack facilities. Meanwhile, international strategic alliances could reduce the cost by using the comparative advantage of each partner. Where, for instance, partners belong to different locations or countries, production can be transferred to the lower cost location or country, hence, this strategy creates greater comparative advantage, certainly. Cost

lowering, in addition, is an incentive for companies to focus on economies of scale even if demand for some products in a particular country may be limited (Mariti and Smiley, at Buckley, 1998). Strategic alliance designated as a part of international managerial strategy, doubtlessly accelerates way in and presence in market of ally partner that consequently provides businesses a golden opportunity achieving long term goals by making their market expansion with products or services being traded internationally that in essence is a real goal of the best part of companies from Kosovo.

\section{Conclusion}

Majority of companies while preparing their business plans, point out some distinguished points among other objectives. Undisputable gaining a certain market share, creating an operational stability and make business expansion are goals the mostly could be read in business plans. The same could be encountered at many companies in the world including companies from Kosovo. Ever since Stabilization and Association Agreement (SAA) was signed between EU and Kosovo, many of companies started modifying and even more creating a new expansion strategy entering in a new gate of large market such are EU. As a result, some of them could struggle and face hard time to get the proper strategies due to the long term operation in a almost closed market, apart from some regional deals some of the companies could have made in past. Applying the right and most suitable strategy for entering in a free large market, barely a few companies could make in no time, hence, the clue could be by embedding a strategy that starts thinking out of the box or with strategic thinking, adding strategic planning, an proper strategic marketing that is mostly needed for new market entrance, and above all international managerial strategy that in sum encompass an appropriate business managerial strategy that stands for expansion and a successive business operation worldwide.

\section{References}

[1] Inkpen, A. \&Ramaswamy, K. (2006). "Global Strategy: Creating and Sustaining Advantage across Borders" Oxford University Press, Inc. New York, USA.

[2] Council of the European Union (October 2, 2015). "Legislative Acts and Other Instruments: Stabilisation and Association Agreement (SAA) between the European Union and the European Atomic Energy Community, of the one part, and Kosovo*, of the other part". Inter institutional File: 2015/0095 (NLE)., Brussels, EU.

[3] Hahn, J. (2015). " Stabilisation and Association Agreement (SAA) between the European Union and Kosovo signed" Press Release Statement 762/15, Foreign affairs \& International Relations, Council of the European Union.

[4] DiVanna, J \& Austin, F. (2004). "Strategic Thinking in Tactical Times" Palgrave Macmillan, New York, USA.

[5] Sloan, J. (2014). "Learning to think strategically - Second Edition" British Library of Cataloging in Publication Data, Routledge, New York, USA.

[6] Herrmann-Nehdi, A. "Creativity and Strategic Thinking: The Coming Competencies" Retrieved January, 2017 from: http://www.co-bw.com/Brain\%20PDFs/StrategicThinking.pdf

[7] Abraham, CH. S. (2012). "Strategic Planning: A Practical Guide for Competitive Success." Emerald Group Publishing Limited, Bingley, UK. 
[8] Kaufman, R., Browne, o. H., Watkins, R. \& Leigh, D. (2003). "Strategic Planning for Success: Aligning People, Performance and Payoffs." John Wiley \& Sons, Inc. San Francisco, USA.

[9] Nickols, F. (2016). "Strategy, Strategic Management, Strategic Planning and Strategic Thinking." RetrievedFebruary, 2017, from: http://www.nickols.us/strategy_etc.pdf

[10] Herrmann-Nerdi, A. "Creativity and Strategic Thinking: The Coming Competencies." Retrieved February, 2017, from: http://asq.org/teamwork/1998/03/leadership/creativity-and-strategic-thinking- the-comingcompetencies.pdf

[11] Simerson, B. K. (2011). "Strategic Planning: A Practical Guide to Strategy Formulation and Execution." Praeger - an imprint of BAC-CLIO, LLC, California, USA.

[12] Steiner, A.G. (1979). "Strategic Planning: What every Manager Must Know" The Free Press-A division of Simon \& Schuster INC. New York, USA.

[13] Sahaf, A. M. (2013). "Strategic Marketing: Making Decisions for Strategic Advantage" PHI Learning Private Limited, Delhi, India.

[14] Ranchhod, A. \&Marandi, E. (2005). "Strategic Marketing in Practice 2005-2006"Elsevier ButterwortHeinemann Linacre House, Jordan Hill, Oxford, UK.

[15] Alkhafaji, F. A. (2003). "Strategic Management: Formulation, Implementation, and Control in a Dynamic Environment" The Haworth Press, Inc. New York, USA.

[16] Aaker, A. D. \&McLoughlin, D. (2010). "Strategic Market Management-Global Perspectives" John Wiley \& Sons, Ltd. West Sussex, UK.

[17] Tallman, S. (2007). "A New Generation in International Strategic Management" Edward Elgar Publishing Limited, UK \& Edward Elgar Publishing Inc. USA.

[18] Buckley, J.P (1998). "International Strategic Management and Government Policy" Macmillan Pres LTD, London, UK \& St. Martin's Press Inc. New York, USA. 